\title{
A Pragmatic Study of Implicit Compliments in Jordanian Arabic
}

\author{
Hussein AlBataineh, (MA)
}

Majmaah University, Saudi Arabia

\begin{abstract}
This paper is a pragmatic study of the speech act of implicit complimenting among Jordanian people. The researcher follows the ethnomethodological approach in order to identify the construction and organization of such a speech act. Such an approach renders the speech act of implicit compliment as an undivided, integral part of the discourse in which it occurs. Adopting this orientation enables the researcher to focus on the motives behind choosing an implicit compliment instead of an explicit one at a specific time of the discourse. The results of the study show that implicit compliments are different from explicit ones and that such a speech act belongs to a different category. The study also shows that implicit compliments convey many interactional functions that serve the speaker and the addressee and that some functions serve them both.
\end{abstract}

Keywords: Implicitness, explicitness, speech act, interactional functions.

\section{Introduction}

According to Holmes (1988:446), a compliment "explicitly or implicitly attributes credit to someone other than the speaker, usually the person addressed, for some 'good' [...] which is positively valued by the speaker and the hearer." This definition deals with this speech act from two sides, namely, explicit and implicit forms of complimenting. Considering the difference between them, we can notice that, according to Boyle (2000:18), compliments can be considered explicit when they "are recognized as compliments outside of context, being realized by a small set of conventional formulae." Leaving aside other context-bound issues such as irony or sarcasm, any ordinary speaker would, in fact, recognize the following expressions as compliments because of their linguistic realization: 'I love your shirt' or 'What a lovely dress you're wearing today!' Explicit compliments are, thus, linguistically realized by declarative sentences which, in turn, can be affirmative or exclamative. There is also a limited lexical choice of verbs (e.g., love, like) and adjectives (e.g., beautiful, nice, lovely). 
However, implicit compliments are those "in which the value judgement is presupposed and/or implicated by Gricean maxims" (Boyle 2000:28). In other words, they do not necessarily have a "fixed" linguistic form like explicit compliments do, and hearers need to infer the corresponding implicature for their interpretation. Boyle (ibid) gives the following examples to illustrate implicit compliments in English: "I wish I could manage my work like you do" and "Your husband is a very lucky man."

The speech act of complimenting is extensively studied in the literature. Golato (2002, cited in Golato, 2003) notices that compliments and compliment responses have been studied in detail in eleven different languages and in six varieties of English alone, and they have been studied from a variety of different perspectives as well (Herbert 1990; Holmes 1988, 1995; Knapp et al. 1984; Wolfson 1983; Nelson et al. 1996; Yu 2003; Placencia and Yépez 1999; Manes and Wolfson 1981, Holmes 1995; Creese 1991; Ylänne-McEwen 1993 among many others). Existing research, in Herbert's words (1997: 488), "deals almost exclusively with explicit compliments."

To the best of researcher's knowledge, only three articles have been directed to the other rarer speech act, namely, implicit compliments (Boyle 2000; Maíz-Arévalo 2012; Bruti 2006). These studies discuss the topic under concern only from one perspective, namely, pragmatics. Boyle (2000:27) argues that the neglect of the study of implicit compliments is caused by two reasons: the methodology used in data collection and the conventional view of phatic communion. Maíz-Arévalo (2012:980) suggests another reason behind such neglect which is the fact that explicit compliments tend to outnumber implicit ones (more than 90\% of her data are explicit compliments). However, Maíz-Arévalo’s focus is not (like that of Boyle’s) on the interpretive procedures employed by interlocutors when receiving an implicit compliment but on the pragmatic motives underlying the speaker's choice of this much rarer speech act. Nonetheless, these two studies and that of Bruti (2006) do not focus on the interactional functions that can be achieved at the time of the compliment event. The researcher argues that a better understanding of implicit compliments can be attained when interactional functions are taken into consideration. This paper is divided into five parts. Section 2 describes the methodology and the data used in the study. Section 3 explains functions of compliments in previous studies. The fourth section explores the interactional functions of Jordanian implicit compliments. Finally, section 5 offers the conclusions and points to future research. 


\section{Data and methodology}

Two different data collection procedures are followed in compliment studies: naturally occurring data analyzed through conversation analytic (CA) methodology, and elicited data collected via a discourse completion task (DCT). Golato argues (2003: 91) that "many studies of compliments and compliments responses do not, in fact, cannot, describe actual language use, simply because their analyses are not based upon data that illustrate actual language use with sufficient granularity." one is interested in finding out how speakers react to compliments in realtime interaction, if one wishes to discern the underlying interactional rules and patterns [...], then DCTs are inappropriate.” Based on the previous justification, the researcher prefers audio- or video- taping of naturally occurring data to investigate the interactional functions of implicit compliments in their natural settings.

The researcher utilizes the ethnomethodological approach for data collection. The data consists of non-elicited, audio-taped face-to-face encounters and spontaneous conversations. The strength of conversation analysis lies in the fact that "its methodology allows for the repeated and detailed analysis of utterances in their sequential context" (Atkinson and Heritage 1984:4, cited in Golato 2003). Thus, the researcher can study the linguistic structures as they are used in real life and in real time. Moreover, tape-recording of conversations enables the researcher to incorporate every element in the interaction (hesitations, laughter, silences and the like) in his analysis.

He bases his analysis on recording transcripts representing the recorded speech situations. After recording the conversation using Samsung S3 mobile as a recording device, the researcher immediately sits down to do a draft transcription to make sure that he still remembers all the contextual information that helps him interpret blurred or unclear words or passages. Moreover, he presents the examples with a brief statement of relevant contextual information to help analyze and contextualize them. And this way of providing the context of each example is especially important for the material since most, if not all, cases depend on reference and context to express meaning. Following Halliday and Hassan's (1976, cited in MaízArévalo 2012:982) notion of "context of situation", the researcher precedes each example in the study by as much contextual information as possible about the field (what the interactants are doing at the time of the dialogue)

93 In addition to the example studies provided by Golato (2003) in her article, all studies mentioned in the previous chapter are not based upon data collected via recording of naturally occurring talk-in-interaction except Boyle (2000) and Maíz-Arévalo’s (2012) studies. 
and the tenor (who are the participants and to what extent their relationship is close).

The population of the study consists of all native Jordanian Arabic speaking people living in Irbid city, Jordan. Over the span of two years, the researcher audio-tapes 64 compliment events which occur in indoor and outdoor activities. Interlocutors are from the lower and the middle class; they occupy different positions (for example, sales people, customers, teachers, school/ university students, managers, workers, etc.). Interactants ranged in age from 5-60 years, with the majority being in their twenties and thirties. All of them live in Irbid city or its villages or camps. Nevertheless, the random sampling technique is used to obtain the sample of the study. The researcher randomly selects the subjects from Irbid City.

\section{Functions of compliments}

Mills (2003) highlights the importance of taking the context into consideration when dealing with any speech act. He states that "compliments can also function in very different ways depending on the context" (219). Unfortunately, the study of compliments has focused on what compliments do in society instead of focusing on what they do in interaction. This narrow view is caused by the way researchers collect their data; Holmes (1988:507) notices that almost all studies adopt ethnographic method for data collection. The study of this speech act has been limited to the explicit form of compliments; consequently, the functions are limited as well. The general, out-of-context functions of compliments have been explained as follows: Wolfson (1983:89) mentions that compliments are social lubricants that create or maintain rapport. By performing this speech event, people can not only maintain mutual harmony but also re-establish reciprocal social relationship. Furthermore, complimenting is also used to alleviate the weightiness of employing a face threatening act (FTA) in the discourse (Holmes 1986; Brown and Levinson 1987). Investigating the pragmatic motives behind the choice of implicit compliments, Maíz-Arévalo (2012: 94) notes that implicit compliments "serve to fulfill a certain range of functions, among the most important being: avoiding face-threat (especially when distance is still relatively high between interlocutors), wishing to sound sincere and/or building rapport."

Apart from Maíz-Arévalo (2012)'s article, the study of compliments has focused mostly on what compliments do in society instead of focusing on what they do in interaction. Further, it is claimed that the ethnographic method used for data collection restricts the researchers' analyses. Therefore, studying the illocutionary force of complimenting, especially implicit compliments, at the discourse level may provide the researcher with some 
plausible findings about the complimenters' intentions or needs to opt for an implicit compliment rather than an explicit one.

\section{Interactional functions of implicit compliments}

It is argued in this paper that there are external (social) and internal (interactional) functions of implicit compliments. External functions are related to the speech act in isolated utterances; thus, they are derived from the speakers' general knowledge about the illocutionary force of the compliments while internal functions are related to the compliment event itself and are derived and determined at the time of the dialogue. The second difference between external and internal functions is that the former concentrates on the illocutionary force; what the speaker wants to do with the compliment, that is to say, the effect of creating and maintaining friendly relationships and that of attending positive and negative face wants (enhancing politeness and saving face). The internal functions focus on the illocutionary and perlocutionary effects behind the use of the speech act under concern; effects on both of the interactants (and possibly on the overhearers as well). Such functions cannot be attained unless the interpreter (whether a participant in the dialogue or not) can sensitively analyze the discourse in order to reach particular impressions resulted and created by the context. Nonetheless, implicit compliments can be used to achieve many different internal (interactional) functions which can serve either the speaker or the addressee as follows:

a- Functions serving the speaker: In certain situations, the researcher notices that the main function of using an implicit compliment at a specific time of the dialogue serves only the complimenter. The following functions are argued to be related more to the complimenter than to the complimentee:

\section{1- Avoiding embarrassment:}

In the following example, the speaker uses a request to pay an implicit compliment since he does not have a close relationship with the addressee. The choice of an implicit compliment is triggered by S's fear of embarrassment.

\section{Example 1}

[Field: A geography teacher who has bought new trainers is walking in the playing yard with another teacher; students are sitting nearby eating and talking during the break.//Tenor: S (male, 15) is one of the students whom $\mathrm{T}$ (male, around 34) had taught three years ago. The relationship between them is formal].

1. S: wallah qaaSdak bhal booT.

2. 'By God, can you lend me your trainers?' 
3. T: imqaddam

4. 'You can take it whenever you like.'

In Jordanian dialect, when somebody says qaaSdak bhal (certain item), the hearer deduces that the speaker admires the item in question. This expression implicitly indicates a compliment (with some exceptions related to different contexts). The usual response would be 'imqaddam' or '9ala Hsaabak' 'take it,' to express thanks. The choice of an implicit compliment in this example helps the speaker avoid potential embarrassment and makes the addressee unconsciously accept the compliment.

\section{2- Solving the verbalization problem:}

The speaker does not have the appropriate lexical items to express his thought, so he tends to use fixed expressions to complete the conversation normally. In other words, the speaker is under considerable pressure to keep on talking during the period allotted to him; he uses implicit compliments to delay the production of a turn in which a decision is anticipated. Examples 2 is illustrative:

\section{Example 2}

[Field: A is desperately searching for a change, $\mathrm{S}$ is sitting in his store.//Tenor: A (male, around 30) and S (male, around 35) are neighbors, but they do not have any relation at all.]

1. A: ma9ak Srafit 9ašara ?

2. 'Do you have a change for 10 dinars?'

3. S: ah (0.9) ta šo:flak yallah (2.1) laqaytlak!

4. 'Yes let me see I have. (( he gives him the change))

5. A: ah hayk (0.3) Sa:r ma9i (0.2) 9išri:n

6. 'Now I have 20 dinars.' ((he did not give him the 10 note, jokingly))

7. S:9aHsaabak.

8. 'You are worthy of them' or 'it makes no difference.'

9. A: allah yis9idak.

10. 'God bless you.' ((thanking))

11. S: tislam.

12. 'Thank you.'

In certain situations the speaker does not have the appropriate lexical items to express his thoughts, so he uses gestures, hand movements and some markers of insufficiency. Such markers are used to provide the speaker with a sufficient time to form a meaningful message. In this example, $\mathrm{S}$ was surprised by the unexpected joke, so he searches his memory for a quick reply; the most appropriate one should be a fixed expression that the speaker has frequently used in similar situations. The implicit compliment ' $9 a$ Hsaabak' helps the speaker solve the verbalization problem. 


\section{3- Supporting the speaker's higher self-esteem:}

Implicit compliments used as self-praise help the speaker maintain his self-image as a respected, worthy human being. It is argued that the existence of some contradictions between the speaker's statements and his actions does not affect this claim since, focusing more on our intentions and conversational goals, we speakers, listen more attentively, to what others say than to our own utterances.

\section{Example 3}

[Field: A, a laundryman, is doing the ironing; D comes to the laundry as a customer, they and begins haggling on the price of ironing two pairs of pants to be less than 80 piasters.//Tenor: A (male, around 40) meets D (male, around 25) for the first time; they do not know each other.]

1. D: qaddayš tu?murni 9alayhum ?

2. 'How much?'

3. A: Өamaniin qirš.

4. ' 80 piasters.'

5. D: ya zalamih ?ana bakuihum b?aql wallah 9ind maHal Oani=

6. 'Oh man, I can have them much less than you ask.'

7. A: 9aHsabak wallah Habibi (1.2) bala maSa::ri.

8. 'If you like, I would do them for you for free, without money(on my bill).'

9. D: Tayb ra9ina ya zalemeh ra9ina ( ).

10. 'Oh man, a little deduction will be okay, please, deduct the cost a little bit further'

11. A: wallahi ya Habibi ya9ni (1.2) bidak tiHsibha 9allaqa::t 9alaqa wkees wkaða=

12. 'You need to think of the expenses; hangers...a hanger, a bag and other things.'

13. D: ?ana ma9ak bas wallahi: ya9ni:: waZ9i ya9ni:!

14. 'I understand, but, By God, well, my position (not having enough money), well.'

15. A: taklufitha 9alayna Ya:lia.

16. 'The expenses are really high.'

17. D: Tayb yallah sab9iin mli::H ?!

18. '70 (piasters) would be okay?!'

19. A: 9aHsaabak (.) miš faarqa. (( lowering his voice))

20. 'You can have them for free, it makes no difference.'

21. D: allah yis9idak allah yis9idak. ((pleading))

22. 'God bless you, God bless you'

23. A: ((no response))

24. D: xalaS ittafaqna sab9iin qirš.

25. 'Let's make a deal, 70 piasters' 
26. A: la? Ma biSiir hayk (.)?ana si9ri wa::Had 9alkul (0.3) si9ir muaHHad.

27. 'Do not argue with me more. I have a fixed price, for all customers.'

28. D: ?ana bakwiihum ib?aqal min hiik.

29. 'I can have them much less than you asked.'

30. A: xalaS xaliiha 9alay ilmarra hay[D: ?allah yis9idak.] la?inaak ?awal mara btiji 9alayyeh [D: ?allah yis9idak.] w9ala Hsaabi wxallina niksabak ibfunjan qahweh [D: ?allah yis9idak bil?afraaH in ša:llah.] billaah 9allayk[D:?allah yis9idak ?allah yis9idak]=

31. 'Let me do them for free this time' [D: 'God bless you, God bless you.' ((thanking))] 'for your eyes, this is the first time you come' [D: 'God bless you.' ((thanking))] 'let me pay the expenses, let's drink coffee' [D: 'God bless you (thanking), at wedding ceremonies, God's willing']

32. D: ya9ni hayk ?aaxir si9ir 9indak.

33. 'This means you've made your mind.'

34. A: ?a:xir si9ir wallah ya Habiibi (.) ?axir si9ir.

35. 'Deduction is impossible, dear, it is the last price.'

((Feeling that $\mathrm{D}$ is not yielding, A draws back and accepts ironing two pairs of pants for only 70 piasters)).

Implicit compliments in this example are used to support the speaker's higher self-esteem. The words in italics 9aHsaabak... bala maSari 'take it for free' and 'xaliiha 9alay 'I'll pay for you' have many implications such as 'you are more important than money, you are a worthy customer and you deserve all respect and admiration' and 'please, do not think of me as a greedy person; money is nothing to me.' The first implication concerning the worthiness of the customer is implausible since each mention of '9aHsaabak' or 'xaliiha 9ali' is followed by an elaboration of the impossibility to make any deduction and the last mention of these positive words is followed by a desperate try of more haggling on the part of the complimentee. Moreover, the idea of the worthiness of the customer had been completely erased when the laundryman states that he has a fixed price, for all clients, therefore, the customer is not special in any way. The second implication is related to the worthiness of the speaker as being a kind, generous person. This implication is more acceptable in this case since the meaning of complimentary phrases suggests that money is nothing to the speaker; the laundryman is repeats '9aHsaabak... bala maSari' and 'xaliiha 9alay' stating that he is going to do ironing for free. Although such offers are ostensible in nature, they support the speaker's high self-esteem. 


\section{4- Following the economy principle:}

The speaker needs/tends to deliver two or more ideas in as few utterances as possible especially when there are limited resources; example 4 exemplifies one of these limitations, namely restricted time during telephone conversations.

\section{Example 4}

[Field: $\mathrm{M}$ is talking to his friend $\mathrm{D}$ over the telephone.//Tenor: $\mathrm{M}$ (male, around 30) meets $\mathrm{D}$ (male, around 26) frequently and they have a close relationship]

1. M: kay:f Haalak?

2. 'How are you?'

3. D: miš naqiSni Viir šooftak

4. 'Seeing you will complete my well-being.'

5. M: ?allah yis9idu

6. 'God bless you.' ((thanking))

The sentence miš naqiSni Viir šooftak can be divided into two parts: miš naqiSni which is the theme of miš naqiSni iši alHamdu lillaah 'I am in perfect health and happiness, thank God'; this reading is related to the most frequent reply in similar phatic talks, and Viir šooftak which is the rheme of ma biddi Yiir šooftak 'I need nothing except seeing you (I miss you).' Combining two sentences in this way is triggered by the economy principle to save time and effort. In support with this suggestion, Papi (2009:160) relates the use of implicitness in natural languages to the fact that "the mind tends to obtain the maximum with the minimum effort[...] as a way of simplifying and speeding information processing." Therefore, implicitness is used "to favour- not to hinder- the functioning of the mind."

\section{5- Showing noble feelings:}

Direct compliments are not acceptable in certain situations when the expected feeling is malicious; example 5 provides an example of such a feeling, envy. To avoid misunderstanding, the speaker opts for implicit compliments and supports them with the religious expression maša? Allah 'Allah's blessings.'

\section{Example 9}

[Field: $\mathrm{M}$ is one of the students who participated in the school broadcast; he recited some verses from the Holy Qur'an. His recitation drew K's attention since it is professional. //Tenor: K (male, 23), a newly employed teacher, does not know $\mathrm{M}$ (male, 11) before this incident; $\mathrm{M}$ is not one of his students.]

1. K: šwai $\mathrm{M} \mathrm{(.)} \mathrm{law} \mathrm{samaHit} \mathrm{ta9aal} \mathrm{?išwai} \mathrm{!}$

2. 'Hey, M, please, come here.'

3. M: ?ana (.) ?aa ?ustaað ! 
4. 'Me? okay, teacher.'

5. K: lamma smi9tak ?ibtiqra bil ?iðaa9a ilyuum (0.4) lafatit ?intibaahi=

6. 'When you recited the Holy Qur'an today, you drew my attention.'

7. $\mathrm{M}$ : in šaalah ma ?axTa?it.

8. 'Had I made a mistake?'

9. K: laa laa miš ?ilqaSid . bass miin darrabak ?ala ttajwiid

10. 'No no, I didn't intend that, but who taught you recitation?'

11. M: ?ana mištarik ibmarkiz qur?aani.

12. 'I have been studying at one of the Qur'anic centers.'

13. K: ibSaraaHa SuuTak ?u tajwiidak maa šaa?a alaah ðakkarni ib9abdil

14. baSiT rahmatu allah 9alayh.

15. 'Honestly speaking, your hypnotic voice and your absorbing recitation

16. remind me of Abdulbasit, may Allah's mercy be upon him.'

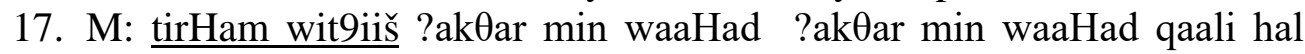
Haki.

18. 'May you be blessed with long life. Many people told me the same.'

In this example, the implicit compliment (lines 13-14) is realized in terms of a comparison in which the speaker draws a parallel between the addressee and a well-known person regarding a specific trait, namely, recitation. The speaker uses the fixed expression maša? Allah 'Allah's blessings' to show noble feelings concerning the addressee's recitation. The use of this expression makes the compliment more appreciative and less face threatening.

\section{6- Expressing gratitude and thanks:}

Implicit compliments are frequently utilized to show that the complimenter is grateful to the addressee for something he has said or done. Consider example 10.

\section{Example 10}

[Field: $\mathrm{T}$ goes to H's store to buy some fruit and vegetables, $\mathrm{H}$ has been recently suffering from heart disease, and most of his neighbors, including $\mathrm{T}$, know that. // Tenor: $\mathrm{T}$ (male, 17) and $\mathrm{H}$ (male, around 50) do not have a close relationship.]

1. T: ?išluunak 9am H. ?išluun ?axbaarak ?išluun SiHtak ?

2. 'How are you, uncle H? How are you doing? How is your health?'

3. H: ?ilHamdulillaah, ?allah ?isalmmak, ?ib ?alf xiir, ?il Hamdulillaah.

4. 'Thank God, God bless you, I'm in perfect health, praise be to Allah.'

5. T: ?išluun ?iššuyul ma9aak?

6. 'Are you satisfied with your work?'

7. H: wallahi ?ilHamdulillaah, ?illi bit9aamal ma9 waaHad mïlak

8. ?ilHamdulillaah, ?ana ?ib ?alf ni9mih wib ?laf xayr . 
9. By God, I’m very well, when I deal with a person like you, everything will

10. be fine, thank God.'

11. T: ?allah yis9idak 9amm $\mathrm{H}$

12. 'God bless you, uncle H.'

\section{7- Substituting for other speech acts:}

The speaker uses implicit compliments instead of other speech acts; the following two expressions are used as indirect criticism and nonnegotiable acceptance respectively.

dammak xafiif 'your blood is light' is used to imply the following: 'you're fun to be around.' This expression is utilized by the complimenter to indicate that after telling an unbelievable story, the addressee is not telling the truth, it is just a matter of exaggeration. Therefore, this phrase is used as an indirect criticism.

?intah faSSil wana balbas 'you sew and I wear' implies that the speaker respects the addressee so much to the extent that he cannot reject his decision; the complimentee is an admirable, wise person who is able to take the right decision. Therefore, this expression serves the function of nonnegotiable, indirect acceptance.

\section{8- Paving the way for other actions:}

An implicit compliment can be used as a preparatory stage for other actions; the following expressions precede haggling and requesting respectively.

rijlak xaDra 'your leg is green' is used on many occasions especially in stores by the sales person to compliment the customer who attracts other customers to the store or by the customer to draw attention to himself/herself, and this implicit self-compliment will be beneficial later on at the moment of haggling.

?iidak Taayleh 'your hand is stretched out' is utilized to compliment a powerful person with good connections who can illegally solve problems by taking the law into his hands. This implicit compliment may be used as a preparatory phrase for a request for a service.

\section{9- Satisfying curiosity:}

Implicit compliments can be used as a suitable vehicle through which people get the information required without appearing inquisitive and rude. Example 11 exemplifies this use. 


\section{Example 11}

[Field: Two friends are having a drink together, one of them is wearing a new, short-sleeved shirt.//Tenor: A (male, 26) and T (male, around 32) have a close friendship.]

1. A: šo:: (.) mištari qamiis jdii:d ?!

2. 'You have bought a new shirt?!'

3. T: $\underline{\text { aah }}$ ištariituh imbariH billayl.

4. 'Yes, I bought it yesterday night.'

5. A:layš ma qultilli, kunt ruHt ma9ak ?u jebtilli waHad zayu.

6. 'Why didn't you tell me? I would escort you and buy a similar one for me

7. T: kunit marir min šari9 issinimah wana rayiH 9assuuq (.) šuftu u9ajabni, šu rayak? Hilu?

8. 'While I was passing-by the Cinema Street in my way to the market, I accidently saw it and thought it is nice. What's your opinion? Is it nice?

9. A: aah mrattab !

10. 'Yes, it is really nice and stylish!'

The complimenter told the addressee that he wants to buy a similar shirt for himself, and the idea is reinforced again at the end of the dialogue when he states that T's shirt is attractive. The implicit compliment here serving the function of satisfying curiosity takes the form of a reprimand. The speech situation consists of (at least) two speech acts, viz. reprimand and compliment, therefore, it can be considered as a macro-speech act, "a global speech act performed by the utterance of a whole discourse, and executed by a sequence of possibly different speech acts" (Van Dijk 1998:356). Therefore, the discourse as a whole can be considered as a macro-implicit compliment (not only the italicized phrases) in which the speech act of reprimand is a "preparatory condition" (ibid) that motivates and leads to the compliment action. However, it is safe to claim that implicit compliments in the form of interrogatives or exclamatory declaratives serve many functions, especially the one related to 'satisfying curiosity.'

\section{0- Indirectly persuading the addressee:}

The complimenter uses an implicit compliment since it is the best way to persuade the addressee of a certain idea, and a direct means of persuasion would be fruitless compared to that of implicit approval and admiration. Consider example 12.

\section{Example 12}

[Field: on a visit to his sister, B has been told by his sister that A, his nephew (male, 4), is unhappy because his outfit is not as colorful and pretty as his brother's. B's sister has told her brother that A had cried all the night and that breaks her heart. At the time of the conversation, B's sister was 
preparing lunch in the kitchen; $\mathrm{B}$ was sitting with his nephew in the parlor. //Tenor: B (male, 33) does not like A as much as his brother since $\mathrm{A}$ is naughty while his brother is more disciplined and cleverer.]

1. B: šu: xaalu ta9aal ?i9Tiini bousih !

2. 'Hey, my nephew, come here, give me a kiss!'

3. A: ?a:: xaalu::::

4. 'Oh, my uncle.' ((coming near))

5. B: maa šaa?a allaah ! (0.5) miin ištaralak hali bluuzeh ? maama willah

6. baaba?

7. 'Oh God, who bought this blouse? Mum or Dad?'

8. A: maama. ištratli yaaha min ?irbid.

9. 'Mum bought it from Irbid.'

Having been told that $\mathrm{A}$ is complaining about his clothes, $\mathrm{B}$ tries to soften the situation and to persuade A that his mother has a clothes sense and his clothes are stylish and elegant, using an implicit compliment suggests that B has not been provided with any information about the event, so the compliment would appear more sincere and genuine. The Implicit compliment serves the speaker with a means to convince the addressee that his clothes are attractive and stylish.

\section{1- Initiating a trouble-telling topic:}

The speaker uses implicit compliments as a transitory stage for introducing an unpleasant topic; such a topic may be deemed as unwelcomed theme to turn the conversation into. In example 13, the speaker utilizes an implicit compliment as an appropriate means to initiate a trouble-telling topic.

\section{Example 13}

[Field: one of the telecom companies has deducted an amount of money from A, a sales person, and that angers him. A harshly complains to the call receptionist, while one of the customers, S, is shopping. //Tenor: A (male, around 33) and S (male, around 20) are neighbors, but they do not have an intimate relationship.]

1. S: bas Hakayt ma9aah bjur?a !

2. 'Oh, in courage and determination you talked to him!'

3. A: ya xi: SaaHib ilHaq qawi, šu ya9ni šu:: ?asawi ? mahum zay ilminšar

4. Taali9 maakil naazil maakil.

5. 'Within your rights, you come on strong. What should I do? They (their

6. policies) are like a saw; both forwards and backwards it cuts (they take

7. money with a right or without a right).' 
8. S: nifsi ?ikuun 9indi jur?a zayyak, haðiik ?ilmarrah-

9. 'I wish to be as courageous as you, last time...

10. A: [hiyyia miš jur?a, bas ilmauZuu9 ?innu ilxaSim miš manTiqi]

11. 'It's not a matter of courage; it's just that the deduction is unjustifiable.'

The speaker admires the addressee for his courage and determination and expresses his wish to be as courageous as the addressee. He uses an implicit compliment in the form of a comparison between the complimentee and himself to initiate a trouble-telling topic. The use of ...haðiik ?ilmarrah'.....that time' reveals that $\mathrm{S}$ is stealing the floor to end A's story and begin a similar one in which he had an unpleasant experience.

12- Gaining access to the floor and shifting the topic from one theme to another:

In example 14, it is explained how the speaker uses an implicit compliment in order to gain access to the floor and to shift the topic from telling jokes to another theme since he does not have any jokes to tell and that makes him stay passive for a considerable time. So, utilizing an implicit compliment at that time of the conversation serves the complimenter a lot.

\section{Example 14}

[Field: Four friends are having a drink together in a cafe. At the time of the compliment, they are telling funny jokes. // Tenor: $\mathrm{H}$ (male, 28), $\mathrm{K}$ (male, 32), $\mathrm{T}$ (male, 30) have an intimate relationship except $\mathrm{M}$ (male, 27) who is recently introduced to the group by T.]

1. M: ya:: ?allaah šu ibtišbah DiHkitak DiHkit SaaHbi !

2. ' 'Oh God, how your laugher resembles that of my friend.'

3. H: šu:: DiHkitu Hilwih ?!

4. 'Is your friend's laughing pleasant?'

5. M: ?aa DiHkituu Hilwih ka?inha Taal?a minilqalb.

6. 'Yes, it is amazing and hearty.'

The speaker comments on H's laugh comparing it to his friend's, intending positive implications, but he has been misunderstood, and the implicit compliment does not have its positive force. According to Van Dijk (1998:348), topic-comment/assertion-presupposition distribution is crucial for the discourse of speech acts; known elements should come in first position and new elements in second position. In the case in hand, the complimenter deviates the given distribution when he associates the complimentee's laugh to that of an unknown person. However, the implicit compliment is utilized to gain access to the floor and to shift the topic from telling jokes to another theme since he does not have any jokes to tell. 


\section{3- Preparing the addressee for certain demands:}

Implicit compliments are used as a preparatory stage for future demands and requests. In example 15, the complimenter uses an implicit compliment to imply that he cannot trust other neighbors, so he has a right or at least a reason to ask similar favors from the addressee, and it will become one of the addressee's moral obligations to accept future demands and requests from the speaker.

\section{Example 15}

[Field: after shopping, $\mathrm{K}$ wants to go to the mosque to attend al-jum'a sermon, he has a heavy bag and does not know where to put it. He decides to put it in the supermarket near his house. // Tenor: K (male, 28) and A (male, around 30) do not have an intimate relationship.]

1. K: marHaba jaar. kayf SiHtak ?

2. 'Hello, my neighbor, how are you?'

3. A: ?allah yis9idak, ?ilHamdullillaah.

4. 'God bless you, fine.'

5. K: bidi ?ayalbak, jaar, biddi ?axalli ?ilkiis 9indak, bidi ?atwaZah wa Salli

6. 'Can I ask you a favor, my dear? I want to leave this bag in your store for I

7. am in a hurry to attend the sermon.'

8. A: wala ihimmak, ya zalama, ?ilmaHal ?u SaHaabu 9ala Hsaabak

9. 'Do not worry, man. Think of the store as yours, and me as your brother

10. (you are welcome).'

11. K: manta ibti9raf, ma ba?ammin bil Haara 9ala Hada ?illa ?inta

12. 'You know, I cannot trust anyone but you in this area.'

13. A: lah ya zalamih, bas maalu ibraahiim ?

14. 'Oh man! What about Ibrahim?'

15. K: ibraahi:::m ?! salaam salaam !

16. 'Ibrahim?! Goodbye goodbye (no comment).'

\section{4- preparing the addressee for departure:}

The speaker uses an implicit compliment as a sign or a hint for leavetaking; in example 15, implicitly complimenting the addressee before his leaving, the speaker indicates that he is interested in his uncle's speech, and his leaving is related to any cause except that of boredom. So, in such a case the speech act of implicit compliment provides the speaker with a means to soften the departure since it is more polite to use an implicit compliment to end the conversation and prepare the addressee for the speaker's leavetaking. 


\section{Example 16}

[Field: $\mathrm{H}$ meets his uncle $\mathrm{S}$ who has recently returned from America. In this visit they talked about many political and social issues. Throughout the conversation, $\mathrm{H}$ could not gain access to the floor except occasionally; his uncle $\mathrm{S}$, being knowledgeable, talkative and charismatic, has been talking all the time, and that considerably impressed $\mathrm{H}$ who has not seen his uncle for two years. // Tenor: H (male, 27) and S (male, 48) are relatives, but they do not have a close relationship.]

1. H: wallaahi la yummal, ibti9raf, Hakiina bmawaZii9 kөiir.

2. 'What a funny time we've spent! (It's nice/ interesting talking to you) Well, we talked about many issues.'

3. S: mauZu::9 bijur mauZu:9, ( ), wilHayaa ( ) -

4. 'One topic leads to another, ... and the life...'

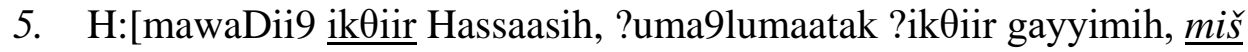

6. ibwijhak! wiSSalaatu 9annabi, mausuu9a]

7. 'Many crucial issues (we've talked about), your information is

8. enlightening. Honestly speaking, (you are) an encyclopedia.'

9. S: kullu min luTfak ?u zuuqak, ?u (.) bas lu nixlaS min hannas ?illi ?illi

10. bni9tabirhum ibniqdar ni9tabirhum SaTHiyyiin, ?u:: ma binZuru ?illa lil

11. gušuur.

12. 'Thank you a lot, you are so kind. Oh, if only other people could think as 13. deeply as you do!’

\section{5- Expressing modesty and avoiding self-praise:}

The speaker uses an implicit compliment to solve the interactional dilemma described by Pomerantz (1978:81-82) in which the recipient of the compliment faces two conflicting constraints, that is to say, to accept the compliment and at the same time to avoid self-praise. Such a dilemma is less imposing when the compliments are delivered implicitly, and as a result, both compliments are appreciated and welcomed in example 17:

\section{Example 17}

[Field: While an English teacher in the classroom was giving a lesson, a student's father came asking about the progress of his son.//Tenor: $\mathrm{H}$ (male, 28) teaches $\mathrm{T}$ (male, around 44) 's son. $\mathrm{T}$ meets $\mathrm{H}$ for the first time.]

1. D: wallahi kfiir irtiHit ?ana ya ostaað (.) lamma: Hakaali $F$ inno raH

2. itdarishum kaman inqli:zi issanih hay.

3. 'By God, I was very pleased when F (my son) told me that you will teach

4. him (as well as his classmates) English this year.' 
5. H: wallahi 9afikra ?ana ixtarthum la?inno F bas biinathum wallah (.) ?allah

6. yis9idak.

7. 'By God, I choose to teach this class only because $\mathrm{F}$ is one of them.'

\section{b- Functions serving the addressee:}

Implicit compliments do not only serve the speaker but also serve the addressee as well. In some situations, the speech act of complimenting is oriented toward a specific goal related to the complimentee as the following functions suggest:

\section{1- Saving the complimentee's positive face:}

The speaker provides an implicit compliment in order to save the addressee from being mocked at. Such a use is exemplified in example 18.

\section{Example 18}

[Field: the family went to Al-Himma for picnic and swim, the next day one of their relatives visited them and asked about their vacation. The following extract centered on $\mathrm{M}$ (male, 8) who is the youngest brother. // Tenor: F (male, 17) meets his cousin R (male, 9) frequently but their relation can be characterized as that of reciprocal rivalry and sometimes enmity.]

1. F: šu: šu::: ?imbariH kuntu tisbaHu ?! kaayf, ma9quul M bi9raf yisbaH

2. 'What a story! Yesterday you were swimming, how about M? I think he

3. could not swim!'

4. R: sa:ma:kah !

5. 'A fish'

6. ((M remains silent and anticipatory))

$\mathrm{R}$ implicitly compliments his young brother in a holistic way; comparing the complimentee's swimming ability to that of a fish is more successful than answering F's question and then defending the complimentee; the latter choice would lead to more arguments and more face-threatening situations.

\section{2- Restoring the addressee's positive face:}

Although highly related to the previous one, this function is completely different; in cases where the speaker uses an implicit compliment to restore the addressee's positive face, the addressee, being a participant of the dialogue, goes fishing for compliments and, consequently, threatens his positive face (see example 19). In the former case (example 18), the addressee does not put himself in the difficult situation in which his face is threatened and he is not a participant of the conversation.

\section{Example 19}

[Field: An English teacher is giving a lesson about present simple, students are tired and bored after having five classes before.//Tenor: the 
relationship between $\mathrm{H}$ (male, around 27) and $\mathrm{C}$ (male, 13) is intimate since $\mathrm{H}$ (the teacher) is friendly and supportive and likes his students. A (male, 13) is another student in the same class.]

1. C: ostaað gaday:: ̌s ?issa9ah ?

2. 'What time is it, teacher?'

3. H: batwagga9iš HiSSti halqad mugrifih !

4. 'I do not expect my class to be that boring!'

5. C: miš qaSdi, ostaað.

6. 'I did not mean that, teacher.'

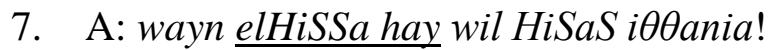

8. 'Compared with other classes, this class is really funny and more

9. interesting.'

10. H: Sadaqtak kөiir wallah. ((teasingly))

11. 'I extremely believe you.'

(A and other students laugh.)

\section{3- Encouraging the addressee:}

The speaker utilizes an implicit compliment in order to strengthen the effect of an utterance in which he wants to encourage the addressee to continue doing something positive. This function is illustrated in example 9 (repeated here as (20) for the sake of clarity):

\section{Example 20}

[Field: $\mathrm{M}$ is one of the students who participated in the school broadcast; he recited some verses from the Holy Qur'an. His recitation drew K's attention since it is professional. //Tenor: K (male, 23), a newly employed teacher, does not know $\mathrm{M}$ (male, 11) before this incident; $\mathrm{M}$ is not one of his students.]

1. K: šwai $\mathrm{M}($.$) law samaHit ta9aal ?išwai !$

2. 'Hey, M, please, come here.'

3. M: ?ana (.) ?aa ?ustaað !

4. 'Me? okay, teacher.'

5. K: lamma smi9tak ?ibtiqra bil ?iðaa9a ilyuum (0.4) lafatit ?intibaahi=

6. 'When you recited the Holy Qur'an today, you drew my attention.'

7. M: in šaalah ma ?axTa?it.

8. 'Had I made a mistake?'

9. K: laa laa miš ?ilqaSid . bass miin darrabak ?ala ttajwiid

10. 'No no, I didn't intend that, but who taught you recitation?'

11. M: ?ana mištarik ibmarkiz qur?aani.

12. 'I have been studying at one of the Qur'anic centers.'

13. K: ibSaraaHa SuuTak ?u tajwiidak maa šaa?a alaah ðakkarni ib9abdil

14. baSiT rahmatu allah 9alayh.

15. 'Honestly speaking, your hypnotic voice and your absorbing recitation 
16. remind me of Abdulbasit, may Allah's mercy be upon him.'

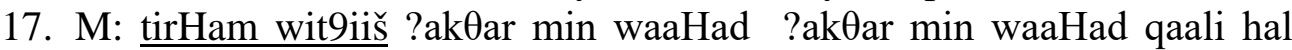
Haki.

18. 'May you be blessed with long life. Many people told me the same.'

\section{4- Making a ground for a previously paid compliment:}

Using an implicit compliment as a continuation of a response to a given compliment, the speaker upgrades the compliment by commenting and reinforcing it. Doing so, he makes the ground for the first compliment and makes himself worthy of receiving it as in example 16 (repeated here as (21) for the sake of clarity):

\section{Example 21}

[Field: $\mathrm{H}$ meets his uncle $\mathrm{S}$ who has recently returned from America. In this visit they talked about many political and social issues. Throughout the conversation, $\mathrm{H}$ could not gain access to the floor except occasionally; his uncle $\mathrm{S}$, being knowledgeable, talkative and charismatic, has been talking all the time, and that considerably impressed $\mathrm{H}$ who has not seen his uncle for two years. // Tenor: $\mathrm{H}$ (male, 27) and S (male, 48) are relatives, but they do not have a close relationship.]

1. H: wallaahi la yummal, ibti9raf, Hakiina bmawaZii9 k0iir.

2. 'What a funny time we've spent! (It's nice/ interesting talking to you) Well, we talked about many issues.'

3. S: mauZu::9 bijur mauZu:9, ( ), wilHayaa ( ) -

4. 'One topic leads to another, ... and the life...'

5. H:[mawaDii9 ik

6. ibwijhak! wiSSalaatu 9annabi, mausuu9a]

7. 'Many crucial issues (we've talked about), your information is

8. enlightening. Honestly speaking, (you are) an encyclopedia.'

9. S: kullu min luTfak ?u zuuqak, ?u (.) bas lu nixlaS min hannas ?illi ?illi

10. bni9tabirhum ibniqdar ni9tabirhum SaTHiyyiin, ?u:: ma binZuru ?illa lil

11. gušuur.

12. 'Thank you a lot, you are so kind. Oh, if only other people could think as

13. deeply as you do!'

\section{c- Functions serving both of the speaker and the addressee:}

Being aimed to serve the speaker or the addressee separately, implicit compliments are found in situations where they are utilized to serve both of the interactants as the following functions indicate. 


\section{1- Avoiding potential problems:}

If the speaker behaves explicitly to express his thoughts, the conversation may turn into a conflict; therefore, utilizing implicit compliments in this way avoids the interaction problems (see examples 2,3 and 13)

\section{2- Creating a smooth atmosphere:}

Compared with the previous function, this one occurs in more conventional situations in which the speaker pays the compliment to reduce an already existing stress, the following two expressions are suggestive.

?9Saabak baardeh 'your nerves are cold = you can take a grip on yourself' can be used to compliment the addressee on his patience in a difficult situation; the complimentee in such a situation can control his emotions although he is afraid, upset or angry; consequently, he is able to behave sensibly and logically.

qalbak ?abyaD 'your heart is white' is used in situations when the addressee has the right to behave maliciously against somebody. The complimenter provides this expression to remind the addressee of his/her noble traits. However, it indicates that the complimentee cannot bear grudges against anyone. The speaker implicitly compliments the hearer in order to reduce stress in a difficult situation (nonetheless, this expression is applicable in other non-stressful situations as well).

To sum up, Jordanian speakers opt for an implicit compliment instead of an explicit one at a specific time of the dialogue to achieve some interactional functions. Such functions are claimed to serve the speaker, the addressee or both as distributed in the following list:

\section{a- Functions serving the speaker:}

1. Avoiding embarrassment

2. Solving the verbalization problem

3. Supporting the speaker's higher self-esteem

4. Following the economy principle

5. Showing noble feelings

6. Expressing gratitude and thanks

7. Substituting for other speech acts

8. Paving the way for other actions

9. Satisfying curiosity

10. Indirectly persuading the addressee

11. Initiating a trouble-telling topic

12. Gaining access to the floor and shifting the topic from one theme to another

13. Preparing the addressee for certain demands

14. preparing the addressee for departure 
15. Expressing modesty and avoiding self-praise

\section{b- Functions serving the addressee :}

1. Saving the complimentee's positive face

2. Restoring the addressee's positive face

3. Encouraging the addressee

4. Making a ground for a previously paid compliment

\section{c- Functions serving both of the speaker and the addressee :}

1. Avoiding potential problems

2. Creating a smooth atmosphere

\section{Conclusion}

The concept of implicit compliment is relatively new to speech act studies not only in Jordanian Arabic but also in other varieties as well. Therefore, this paper examines the speech act of implicit compliment used by Jordanian people within its larger context to raise awareness among those who are not acquainted with it. It is a modest attempt to delve deeper into the compliment event to reach the interactional functions of implicit compliments. This study focuses on the motives behind choosing an implicit compliment instead of an explicit one at a specific time of the discourse.

The results of the study show that implicit compliments are different from explicit ones and that such a speech act belongs to a different category. The study also shows that implicit compliments convey many interactional functions that serve the speaker and the addressee and that some functions serve them both. It presents fifteen functions related to the speaker, four functions connected with the addressee and just two related to both of them. Amazingly enough, implicit compliments, although directed to the addressee, are found to have more functions related to the speaker, and this finding suggests that speakers using implicit compliments are self-oriented people; the constitution and timing of this speech act are found to benefit the complimenter in the first place. Consequently, the researcher hypothesizes that an implicit compliment is a self-oriented speech act, while an explicit compliment, on the other hand, is an other-oriented speech act $^{94}$. Nevertheless, it is safe to say that an implicit compliment is a functionindicating device that serves many interactional functions and implicit compliments are not always used phatically.

94 Such a claim needs to be confirmed by other studies on the speech act in hand. Unfortunately, previous researchers have studied and treated compliments according to their general world knowledge of the benefits and reasons of using this speech act, in addition to their treatment of implicit and explicit compliments as being two sides of the same coin. The researcher argues that in order to see clearly the differences between implicit and explicit compliments, researchers need to consider them as two different speech acts. To reach this end, researchers need to study implicit compliments from within, i.e., at the discourse level. 


\section{References:}

Atkinson, J. \& Heritage, J. (1984). Structures of Social Action: Studies in Conversation Analysis. Cambridge: Cambridge University Press.

Boyle, R. (2000). 'You've worked with Elizabeth Taylor!': Phatic Functions and Implicit Compliments. Applied Linguistics, 21(1), 26-46.

Brown, P. \& Levinson, S. (1987). Politeness: Some Universals in Language Usage. Cambridge: Cambridge University Press.

Bruti, S. (2006). The Translation of Implicit Compliments in Subtitles. The Journal of Specialized Translation, 6 (1),185-197.

$<$ http://www.jostrans.org/issue06/art_bruti.pdf $>$

Creese, A. (1991). Speech Act Variation in British and American English. Penn Working Papers in Educational Linguistics, 7 (2), 37-58.

$<$ http://www.gse.upenn.edu/wpel/sites/gse.upenn.edu.wpel/files/archives/v7/ v7n2Creese1.pdf $>$

Halliday, M. \& Hassan, R. (1976). Cohesion in English. Malaysia: Pearson Education Ltd.

Herbert, R. (1990). Sex-based Differences in Compliment Behavior. Language inSociety,19,201-224. $<$ http://www.jstor.org/discover/10.2307/4168132?uid=3738320\&uid=2129\& uid $=2$ \&uid $=70$ \&uid $=4 \&$ sid $=21101357802791>$

Herbert, R. (1997). The Sociology of Compliment Work in Polish and English. In: N. Coupland and A. Jaworski (Eds.), Sociolinguistics(pp. 487500). London: Macmillan.

$<$ http://www.deepdyve.com/lp/de-gruyter/the-sociology-of-complimentwork-an-ethnocontrastive-study-of-polish-qsB6kSp2GR>

Holmes, J. (1986). Compliments and Compliment Responses in New Zealand English. Anthropological Linguistics, 28(4), 485-508.

$<$ http://www.jstor.org/discover/10.2307/30028355?uid=3738320\&uid=2129 \&uid=2\&uid=70\&uid=4\&sid=21101357802791 $>$

Holmes, J. (1988) Paying Compliments: A Sex Preferential Politeness Strategy. Journal of Pragmatics, 12, 445-465.

< http://www.sciencedirect.com/science/article/pii/0378216688900057>

Holmes, J. (1995). Women, Men and Politeness. London: Longman. <http://www.questia.com/library/3149271/women-men-and-politeness>

Knapp, M., Hopper, R. \& Bell, R. (1984). Compliments: A Descriptive Taxonomy. Journal of Communication, 34(4), 12-31.

$<$ http://onlinelibrary.wiley.com/doi/10.1111/j.14602466.1984.tb02185.x/abst ract $>$

Maíz-Arévalo, C. (2012). 'Was that a compliment?’ Implicit Compliments in English and Spanish. Journal of Pragmatics, 44 (1), 980-996.

Manes, J. \& Wolfson, N. (1981). The Compliment Formula. In: F. Coulmas(Ed.), Conversational Routine (pp. 115-132). Mouton: The Hague. 
Mills, S. (2003). Gender and Politeness. Cambridge: Cambridge University Press.

$<$ http://www.cambridge.org/gb/knowledge/isbn/item1114321/?site_locale=e n_GB $>$

Nelson, G., Bakary, W., \& Batal, M. (1996). Egyptian and American Compliments: Focus on Second Language Learners. In S. M. Gass and J. Neu (Eds.), Speech Acts across Cultures: Challenges to Communication in a Second Language (pp. 109-128). Berlin: Mouton de Gruyter.

$<$ http://applij.oxfordjournals.org/content/17/4/411.short>

Placencia, M. \& Yépez, L. (1999). Compliments in Ecuadorian Spanish.Revista Lengua, 9 (1), 83-121.

< http://www.carla.umn.edu/speechacts/bibliography/compliments.html> Wolfson, N. (1983). An Empirically Based Analysis of Complimenting in American English, In N. Wolfson and E. Judd (Eds.), Sociolinguistics and Language Acquisition (pp. 82-95). Rowley Mass: Newbury House.

Ylänne-McEwen, V. (1993). Complimenting Behaviour: A cross-cultural Investigation. Journal of Multilingual and Multicultural Development,14(1), 499-

$<$ http://www.tandfonline.com/doi/abs/10.1080/01434632.1993.9994551\#pre view>

Yu, M. (2003). On the Universality of Face: Evidence from Chinese Compliment Response Behavior. Journal of Pragmatics, 35, 1679-1710. <http://www.sciencedirect.com/science/article/pii/S0378216603000742> 